\title{
And Now A Word About Secular Humanism, Spirituality, and the Practice of Justice and Conflict Resolution
}

Carrie Menkel-Meadow

Georgetown University Law Center, meadow@law.georgetown.edu

Georgetown Public Law and Legal Theory Research Paper No. 288804

This paper can be downloaded free of charge from:

https://scholarship.law.georgetown.edu/facpub/525

http://ssrn.com/abstract=288804

28 Fordham Urb. L.J. 1073-1087 (2001)

This open-access article is brought to you by the Georgetown Law Library. Posted with permission of the author. Follow this and additional works at: https://scholarship.law.georgetown.edu/facpub

Part of the Dispute Resolution and Arbitration Commons, and the Legal History Commons 


\title{
AND NOW A WORD ABOUT SECULAR HUMANISM, SPIRITUALITY, AND THE PRACTICE OF JUSTICE AND CONFLICT RESOLUTION
}

\author{
Carrie Menkel-Meadow*
}

The papers presented in this Dialogue raise very important and moving questions about the relationship of spirituality, moral values, and religion to the practice of law generally, and the practice of conflict resolution specifically. In this Commentary, I want to focus on two related questions: First, where do our moral values, spirituality, and sense of communion or connection come from? And second, how do values derived from various sources of secular humanism inform our practices? For some of us, organized religion is not the primary source of our commitment to the "moral" values that inform our legal and conflict resolution practices, but other values or values surprisingly similar to religious values do inform our work. This Commentary addresses some of those alternative sources of "spiritual values," as used by the participants in this Dialogue.

\section{SOURCES OF VAlues}

For many of us, spiritual values, morality, and religion are "given," not chosen, in the sense that we accept what our forebears, our culture, our family, and our racial, ethnic, or religious birthright, or "birth responsibility," gives us. For others of us, our sense of spiritual place and values has been "chosen" by conversion, commitment, reattachment, or detachment from birthed endowments. For some of us, spiritual values and religion are separate from our professional lives; for others of us, we have sought to inform professional practice either with traditional reli-

* Professor of Law, Georgetown University Law Center; Visiting Professor of Law, Harvard Law School, 2001; Chair, CPR-Georgetown Commission on Ethics and Standards in ADR. Thanks to Gary Menkel, Jack Himmelstein, and Howard Lesnick for decades worth of spiritual discussions. 
gions $^{1}$ or with modern and eclectic self-chosen notions of spirituality, ${ }^{2}$ mindfulness, ${ }^{3}$ or alternative sources of moral values. ${ }^{4}$

Where do our senses of moral commitments come from? Must moral commitments be religious in nature? What does it mean to speak of "spiritual" values in human action and in professional practice? Can one be moral and spiritual, or have one's professional practice informed by spiritual and moral "values," without being religious?

These are big questions and I will not do them justice here. But I want to "intervene" this Commentary in the otherwise learned discussions in this Dialogue and raise another voice by asking some more questions about what the values are that inform our practices, and suggesting some other sources for their origins and development.

I begin with a brief biographical note since I will focus on "chosen," not given, aspects of spiritual values. I am the daughter of Holocaust survivors, both German, one Jewish, one Catholic, who arrived in the United States during the diaspora of the Second World War. Both of my parents were comfortable in Germany

1. E.g., Joseph Alegretti, The Lawyer's Calling: Christian Faith and Legal Practice (1996); Joseph Alegretti, Lawyers, Clients and Covenant: A Religious Perspective on Legal Practice and Ethics, 66 Fordham L. Rev. 1101 (1998); Howard Lesnick, Listening for God: Religion and Moral Discernment (1998); Thomas L. Shaffer, Faith and the Professions (1987); Thomas L. Shaffer, On Being a Christian and A Lawyer: LaW for the InNocent (1981); Russell G. Pearce, Foreword: The Religious Lawyering Movement: An Emerging Force in Legal Ethics and Professionalism, 66 Fordham L. Rev. 1075 (1998).

2. E.g., Zena D. Zumeta, Spirituality and Mediation, 11 Mediation Q. 25 (1993) (defining spirituality as "an awareness of the connectedness of all things," and discussing ways to bring it into mediation); Steven Keeva, Transforming Practices: Finding JoY and Satisfaction in the Legal Life (1999) (describing the approaches and techniques of seven kinds of spiritually oriented law practices).

3. E.g., Len Riskin, The Contemplative Lawyer: On the Possible Contributions of Mindfulness Meditation to Law Students, Lawyers and Clients (unpublished manuscript, on file with author). For an organization doing excellent work in, among other things, organizing meditative retreats for law students, lawyers, and law professors in collaboration with Yale University Law School, see Center for Contemplative Mind in Society, Northampton, Massachusetts at http://www.contemplativemind.org (last visited Mar. 17, 2001).

4. For many years, for example, I was associated with a group of legal educators who were using humanistic psychological principles to address "deeper" human values in the law. E.g., Becoming a Lawyer: A Humanistic Perspective on Legal Education and Professional Identity (Elizabeth Dvorkin et al. eds., 1981) (considering the impact that work in humanistic eduation can have on legal education); Jack Himmelstein, Reassessing Law Schooling: An Inquiry into the Application of Humanistic Educational Psychology to the Teaching of Law, 53 N.Y.U. L. Rev. 514 (1978) (proposing the use of "humanistic educational methodologies" in law school education as a way to enhance the profession). 
before their immigration and after some struggle and harrowing experiences, ${ }^{5}$ became "comfortable" again. But in my family, where the Holocaust was revisited constantly in conversation and retelling of experiences, ${ }^{6}$ the conclusion was not to cling to our different religious traditions, ${ }^{7}$ but to see the harm that religious and racial "belonging" to hate and violence. For me, religious and racial divisions and differences meant horrific violence, and so my childhood was spent thinking about ways to reduce such human suffering. My parents strongly rejected their own traditional religious birthrights and I was raised in the quasi-secular religious crucible of Ethical Culture in the religious "revival" of the 1950s."

The religion of the Ethical Culture Society, founded by Felix Adler out of the social, political, and religious progressivism of late nineteenth century American optimism, was, in the 1950s, a strange mixture of quasi-religious tenets, such as "God is spelled with two o's (Good)," and political commitments. ${ }^{10}$ Most members in New York also were active in SANE, ${ }^{11}$ the anti-nuclear movement, and the Civil Rights movement. Children attended the Encampment for Citizenship, a multi-racial summer camp, which sought to teach children tolerance and appreciation for civil rights and international human rights along with a 1950s-acceptable ver-

5. These included Kristallnacht, Nov. 9-10,1938, a 1941 last-boat-out transatlantic passage, much suffering in racial labeling, acts of discrimination, seizure of property and self-respect, and, of course, the death of family members, friends, and lovers. My parents were lucky - they survived and became comfortable again (in family and in economics-the psychological harms are incalculable).

6. All of my grandparents survived to spend twenty years of Sundays at my childhood home telling stories in the German I learned to understand as a child deciphers parental languages.

7. We celebrated the Christian ones-Christmas and Easter-in full pagan and secular splendor, with both German and American traditions. I was born on Christmas Eve.

8. For an eloquent report on modern religious and ethnic wars, see MiCHAEL Ignatieff, Blood and Belonging: Journeys into the New Nationalism (1993).

9. Robert Bellah et al., Habits of the Heart: Individuals and Community in American Life (1985); Robert Putnam, Bowling Alone: The Collapse and Revival of American Community (2000); see also Peter Berger, The SaCRed Canopy: Elements of a Sociological Theory of Religion (1967) (describing the history and process of secularization).

10. E.g., Felix Adler, A New Statement of the Aim of the Ethical Culture Society (1904); Algernon Black, Ethical Culture: A Living Faith for MODERN MAN (1963).

11. SANE is the Committee for a Sane Nuclear Policy. E.g., Milton S. Katz, Ban The Bomb: A History of SANE: The Committee for a Sane Nuclear POLICY 1957-1985 (1986). 
sion of basically socialistic principles, appropriately labeled an "experiment in democratic processes." 12 My Sunday School classes consisted of study of many of the world's religions, including Buddhism, Zoroastrianism, Shintoism, Islam, Catholicism, Judaism, Protestantism, Taoism, and Hinduism. We also read Margaret Mead to learn about the human diversity in culture and living practices, and were introduced to sociology (in which I later majored in college) and humanistic philosophy. The obvious "morality" of this education was not biblical or talmudic doctrinal study and inculcation. Its purpose was to foster a sense of awe at human variation, and a curiosity and thirst for understanding others' lives, practices, traditions, and cultures. Most importantly, it sought to foster an internalization of something much greater than "tolerance"- "appreciation" for difference as well as disgust for ethnic and religious imperialism, coercion, conversion, violence, and wars. We all worked for peace and disarmament-very important and difficult values to work for in the era of the Cold War-and for civil rights (which is why peace, justice, and harmony always have seemed fused for me in dispute resolution work, not separated or antagonistic, as some have argued they are)..$^{13}$

So religious birthrights can be replaced by formative experiences (e.g., the Holocaust) that challenge, as well as reinforce, that into which we are born. For many in my generation, religious sources of values were trumped by political commitments. For those of us who took part in the political movements of the 1960s, including the Civil Rights, feminist, War on Poverty, anti-war, and, more recently, gay rights movements, various versions of "equality" and "justice" were as important to us in any value structure as religious fidelity, chastity, worship, fellowship, and devotion to any deity or form of religious doctrine. As odd as it may seem today in 2001, our "gods" or quasi-religious figures were Karl Marx, Che Guevera, Martin Luther King, and, for me, Susan B. Anthony, Elizabeth Cady Stanton, Simone de Beauvoir, and Michael Harrington (author of The Other America). ${ }^{14}$ Beginning with Karl

12. Algernon Black, The Young Citizens: The Story of the Encampment FOR CITIZENSHIP (1962) (describing the principles, purposes, history, and ideals of the Encampment movement).

13. E.g., Laura Nader, Controlling Processes in the Practice of Law: Hierarchy and Pacification in the Movement to Re-Form Dispute Ideology, 9 OHIO ST. J. ON DisP. RESOL. 1 (1993) (arguing that the dispute resolution movement is based on a "harmony ideology" that often has the coercive effect of pacifying participants).

14. Michael Harrington, The Other America (1962). This book is credited with suggesting to President Kennedy the basic blueprint for what became the War on 
Marx, these "religious preachers" taught us to see that class injustice, whether organized by caste (race or gender) or by status (slave, laborer, or wife) was systematic, oppressive, and immoral. We saw that human beings could be the authors and agents of their own lives, rather than passively accepting their lots (remember that "religion is the opiate of the people")..$^{15}$ Thus, a belief in the centrality and importance of human, not divine, agency ${ }^{16}$ was critical to the "faith" of the 1960s. Our tenets of equality and fairness, as well as equity and justice, were informed by a respect both for individualism and a communalism that sought to be far more inclusive than traditional family, religious, or nation-state formations. As political activists of the 1960s organized around labor, race, gender, economic, anti-war, and life-style ${ }^{17}$ issues, they formed alternative institutions (communes, group homes, participatory networks, labor alliances, new relationships, and political organizations $)^{18}$ that many believed would supplant traditional forms of family, religion, and workplace. These commitments were (and still are, for some) as strong as any of the more traditional pulls of religious or familyinspired morality. There was moral teaching in these movements: people were to be treated as ends, not means; oppression of one person or one class by another was wrong; individuals should be free to self-define their destiny, and human resource allocation should be just and fair.

Feminism taught another set of moral precepts. Some, such as a belief in equal opportunity for individuals and disapproval of oppression and inequality, were consistent with other political move-

Poverty. It was one of the inspirational texts for me in my decision to be a Legal Services lawyer for the poor. For a modern and equally moving account of how Legal Services lawyers are committed to the amelioration of poverty and human and political suffering, see Melissa Fay Greene, Praying for Sheetrock (1991).

15. Karl Marx \& Frederick Engels, The Communist Manifesto (Verso 1998) (1848).

16. Recall that the Enlightenment's emphasis on human agency and "humanism" was itself considered a counter-religion or counter-faith to the religious teachings it was seen to supplant. "Humanism" was itself a religion for many in the eighteenth century.

17. As a sociology student I wrote a paper in the 1970s suggesting that the social revolution (divorce, changed sexual practices, racial and religious intermarriage, unmarried cohabitation, media access, etc.) likely would have longer lasting societal effects than the "political" revolutionary dreams and hopes of the 1960s. Was I right?

18. Consider the "flowering" of new political organizations like NOW (the National Organization of Women), SNCC (Student Non-violent Coordinating Committee), SDS (Students for a Democratic Society), and the Black Panthers. The political spectrum of these groups ranged from organized legal activity such as that of the NAACP (National Association of the Advancement of Colored People) LDF (Legal Defense Fund), to more radical activity (e.g., the Weather Underground). 
ments. Feminism also challenged contemporary thinking, eventually teaching (after some struggle within the movement itself) to valorize certain traditional "feminine" values. These included care for others, ${ }^{19}$ mercy ${ }^{20}$ concerns for the "needs" as well as instrumental "interests" 21 of others, and belief in a necessity for the larger society to play a role in sharing the care that any social grouping requires. Women's consciousness raising groups, encouraging the "sharing" of experiences, the telling of narratives about oppression and pain as well as the triumphant stories of freedom gained, were, for many of us, substitutes for more traditional communal and religious gatherings. Women organized such ceremonies as feminist Passover Seders and "crowning" and "croning" rituals to mark different passages in women's lives and to create different kinds of sacred places and celebrations. For many, the Woman's Movement was both political and spiritual-women who were separated from each other by traditional family roles found new kinship and loyalties. Explicitly, in both scholarship and practice, feminists sought to develop alternative value structures while seeking transformed relationships at home and in the workplace. Women reached out with their altered practical and spiritual connections in attempts to affect the larger society in which they were embedded. ${ }^{22}$

After the political and cultural revolutions of the 1960s dissipated $^{23}$ and were replaced by the more materialistic and selfish 1980s and 1990s, a different form of spiritualism arose, one that drew us inward. Many Americans, seeking spiritual enlightenment, sought solace and different religious experiences in the religious

19. See generally Robin West, CARING for Justice (1999).

20. E.g., Carrie Menkel-Meadow, Portia In A Different Voice: Speculations on a Women's Lawyering Process, 1 Berkeley Women's L.J. 39 (1985) (discussing social conditions of women lawyers and offering alternative values practiced by women lawyers); see also William Shakespeare, The Merchant of Venice act 4, sc. 1 (depicting Portia, a noblewoman posing as a Doctor of Laws, telling Shylock, a usurer, that mercy should temper justice).

21. E.g., Carrie Menkel-Meadow, Aha!? Is Creativity Possible in Legal Problem Solving and Teachable in Legal Education, 6 HARv. NEGot. L. Rev. (forthcoming 2001).

22. E.g., Knowledge, Difference \& Power (Nancy Goldberger et al. eds., 1996) (describing different and gendered "ways of knowing theory" and illustrating alternative methods of perceiving and understanding gender and knowledge).

23 . We are probably still too close to these movements to analyze them ourselves, though that has not stopped many participant-historians from seeking to explain just what happened to the mass commitments of this era. E.g., TODD GitLin, THE SiXties: Years of Hope, Days of Rage (1987); Reassessing the Sixties: Debating the Political and Cultural Legacy (Stephen Macedo ed., 1997). 
and meditative practices of the East, particularly various forms of Zen Buddhism and a variety of "New Age" eclectic forms of mindfulness and reflective practice. If we could not be successful in changing the conditions of the material world (or alternatively, if we were too "successful" in the material world) we could turn to inner reflection and enlightenment as a source of peace, tranquility, and harmony. We could contemplate and focus on the nonmaterial and spiritual world either as self-defined or as learned in apprenticed years of contemplative practice and study.

So when I think of the places where our moral and spiritual values are learned, I find that more influences than only traditional religious doctrines and practices inform how we think of our place in the world as human beings, citizens, or moral people. The family, religious practice, and life experiences that form political and secular, as well as religious alliances, all affect our consciousness and moral "leaning."24 Thus, I want to suggest that "secular humanism," as I have described at least one version of it (my own) here, is itself a source of spiritual and moral values that informs both the practice of law generally and the practice of conflict resolution particularly. Let me suggest briefly which values I believe are informed by secular humanism and explain why secular humanism, in my view, should be credited, as much as traditional sources of religious, moral, and spiritual learning, with providing informative and inspirational tenets for our practices.

\section{The Values that Inform Conflict Resolution Practice}

Whatever the discipline from which we choose to recognize our values, I think that all of us at this conference, or readers of this Dialogue, share a sense that our professional practice should be informed with human significance, meaning, and "good" values. "Good" values enhance human flourishing, promote respect for others, allow us to recognize our human commonalities and connections as well as our individual differences, and enable us, through our own actions, to make the world a better place than we found it. In this, lawyers (conceived as human and social problemsolvers) and mediators or conflict resolvers (as peacemakers and

24. Note that I have not discussed secular professional moral norms and rules here which is a bit odd for a legal and dispute resolution ethicist, but in fact, I think such rules and regulations do not form our "moral consciousness." We consult such rules and regulations for guidance or for post hoc rationalization of actions and moral stances that I believe are actually framed, at least initially, outside of these official and regulatory boxes. 
healers) can find some common purposes. But it is also important, I think, to trace and consider our differences. Just as there are "false cognates" in languages there are also "false cognates" when we assume that words have the same meaning in different contexts. Litigative lawyering is not the same as mediational lawyering, just as not all religious and spiritual traditions mean the same thing when they speak of "holiness" or "salvation." So, focusing on my starting place of a more secular experience of humanism and spirituality-expressed as care for the other, as well as the self-and with a heavy dose of political "justice," I will outline briefly the values that I think are crucial to our practice as dispute or conflict resolvers. ${ }^{25}$

Conflict resolvers begin with different perspectives on conflict. There is a great deal of talk in our field today about "managing" or "resolving" conflict, and many are drawn to the work of conflict resolution in order to make peace or deal with unproductive conflict. But others, especially those of us from the secular humanist group I have outlined above, were reared in conflict-familial generation gaps, struggles with authority for self-determination and redefinition of the person, fights and arguments with lovers, bosses, and friends over racial and gender equality. The Civil Rights movement included both Mahatma Ghandi's and Martin Luther King's "passive resistance" and "non-violent civil disobedience,"26 but it also included a great deal of conflict, some unfortunately physical, and much of it hostile and verbal. Conflict in the contexts of some of those political struggles allowed spiritual realignments as whites joined blacks and some men joined women in these efforts. "We Shall Overcome," the anthem of the Civil Rights movement, is both a "spiritual" song and a call to action. Thus, some of us see growth and movement, transformation, realignments, social change, and justice emerging from conflict, so that not all conflict is

25. Within our field, "dispute" is usually intended to connote the concrete argument, dispute, or rupture that causes a problem, disagreement, or lawsuit. "Conflict" is the larger relationship or set of issues in which the concrete dispute may be located. Lawyers, mediators, arbitrators, consensus builders, and other dispute professionals work at both levels. Within our own discipline there is healthy disagreement about whether disputes are simply "settled" or whether conflicts or people can be "transformed" through our practice. E.g. Robert A. Baruch Bush \& Joseph P. Folger, The Promise of Mediation (1994); $c f$. Carrie Menkel-Meadow, The Many Ways of Mediation: The Transformation of Traditions, Ideologies, Practices and Paradigms, 11 NEG. J. 217 (1995).

26. Peter Ackerman \& Jack Duvall, A Force More Powerful: A CenTURY OF NON-VIOLENT CONFLICT (2000) (describing the significant non-violent conflict political movements of the twentieth century). 
bad and not all conflict must be "managed" or "resolved." I prefer to speak of conflict "handled" or "channeled" (productively). Struggle for liberation is part of The Bible and also part of a political story. The search for liberation and autonomy is one of those human universals. So is the search for connection. What is not so universal is how much violence or physical harm we must endure or how much may be justified to right some of the human wrongs we seem to inflict on each other. (What is self-defense and what is aggression at the inter-personal, as well as international, level?) Thus, what we think about the relationship of peace and harmony to justice may inform how we exercise our practice. Sara Cobb's essay in this Dialogue ${ }^{27}$ suggests an active, dare I say "ministerial" or "pastoral," role for the mediator. In this role, the mediator actively engages parties in creating a narrative that brings conflict to the fore so it can be examined, "moralized," and reconstructed in proposed future actions to alter the relationship of the parties. Conflict is framed and scrutinized in order to examine identity, meaning, roles, and morality and to create change and a more "moral" relationship. The mediator is active, rather than passive, in the creation, description, and use of conflict, all presumably to achieve a higher purpose and a better relationship for the parties (and the larger workplace in which they are embedded).

Even with a great deal of conflict expressed in a mediation or other dispute resolution setting, including litigation, we know we serve a higher purpose in the not-so-linear development of the human species. Mediation, arbitration, negotiation, and yes, even litigation, are substitutes for armed physical violence. We have moved from "trial by combat" to "trial by words." We hope, if we can deal with the "disputes" among us (both individuals and groups) then maybe we can prevent or discharge some of those disputes that would ripen into the larger "conflicts" that cause war and killing. So we seek peace, if not total harmony, even when we are at our worst in verbal combat.

At our best, conflict resolution professionals seek to express values other than simple "peace," dispute settlement, or cessation of violence. Many of us prefer the instrumental, Pareto-optimizing 28 sense of solving problems in a participatory, open, and party-di-

27. Sara Cobb, Creating Sacred Space: Toward a Second Generation Dispute Resolution Practice, 28 Fordham URB. L.J. 1017 (2001).

28. Pareto-optimizing means that each party has maximized its own gain without further harm to the other party. It represents the most "efficient" outcome. HowarD Raiffa, The Art and Science of Negotiation 139 (1982). 
rected setting to the binary, third-party neutral structure of litigation or arbitration ${ }^{29}$ that has routinized or regularized outcomes imposed from on high or from without. For others of us, it is the "reconciliation" 30 of human beings or transformation of relationships, which Albie Davis called the "magic" of mediation, ${ }^{31}$ and Sara Cobb calls the "sacred" 32 moment of understanding and reorientation to another human being, as well as the self. For those of us who have experienced these moments, they are about changes in individuals and relationships as well as social and political change. They can be about justice as parties reorient themselves in ways that seem more fair and honest and in which they make new promises to each other (the ceremony or ritual of mediation, captured here by Sara Cobb). ${ }^{33}$ They may enable people to be further connected to a larger community, not just of two, but of others with whom they are associated-the family, the workplace, or some other community. ${ }^{34}$

But the secular humanist teachings to which I refer above also lead us to other values. Feminism has asked us to take caring for others seriously, as we recognize that we are not all always equal. As the disability community suggests, we are all "temporarily abled," most of us requiring care at early and late stages of the life cycle and some of us requiring care for longer periods than that. From our illnesses and differentially abled places, we should acknowledge the interdependence of human beings in all places, including in the family, the workplace, the place of worship, the daily commute, or the gym. We need and depend on each other, and fundamental human "needs" as well as instrumental "interests" need to be recognized and reconciled. We must learn to trust each other while giving and receiving care. Although some rail against the power inequalities in mediation or other forms of alternative dispute resolution ("ADR"), I suggest that mediation and some

29. Martin Shapiro, Courts: A Comparative and Political Analysis (1981) (describing the elements of the classical adjudicatory and dispute resolution triad).

30. Andrew McThenia \& Thomas Shaffer, For Reconciliation, 94 YALE L.J. 1660 (1985).

31. Albie Davis, The Logic Behind the Magic of Mediation, 5 Neg. J. 17 (1989).

32. Cobb, supra note 27.

33. Id.

34. E.g., Clark Freshman, Privatizing Same-Sex "Marriage" Through Alternative Dispute Resolution: Community-Enhancing Versus Community Enabling Mediation, 44 UCLA L. Rev. 1687 (1.997) (arguing that "community-enabling mediation" is an effective way for same sex couples to create a marriage-like union and connect to the larger communities, both gay and straight, in which such couples live). 
forms of ADR are most appropriate for honestly addressing inequalities and meeting the needs of unequal parties. In mediation, people can recognize and face up to their human responsibilities, not because someone has ordered them to, but because they have come fully to understand and comprehend someone else's reality and limitations.

ADR or conflict resolution practices acknowledge a greater human variability of action than do the ritualized or overly stylized forms of litigation practice. This allows values other than being "right" to be imagined and enacted. Portia's plea for mercy ${ }^{35}$ or forgiveness, the granting of an apology ${ }^{36}$ and human acknowledgment of wrongfulness, if not legal fault or blame, all allow the fuller expression of a richer gamut of human actions, emotions, and feelings and we hope, a more humane set of responses.

At the same time, secular humanist movements that see "justice" as equally important a value as forgiveness and reconciliation, remind us that conflict resolution practices must serve many masters. It is not enough to provide a location for a sacred ceremony or a ritual of understanding and reconciliation if injustices remain. Thus, conflict resolution professionals have learned to create their own doctrines that recognize substantive values (equality, liberty, self-determination, equity, and fairness ${ }^{37}$ ) as well as process or "ceremonial" values (participation, "voice," and groundrules). And related to this, for me, is the misconception held by many that mediation cannot promise justice because it offers up too much compromise. In this Dialogue, Professor Bush traces the recognition of compromise in the Talmud, as a "preference for ADR" over rabbinical judgment. ${ }^{38}$ The motivation is one I heartily agree with-that the parties are better off coming to their own terms

35. Menkel-Meadow, supra note 20; ShAKESPEARE, supra note 20.

36. E.g. Jonathan R. Cohen, Advising Clients to Apologize, 72 So. CAL. L. Rev. 1009 (1999) (discussing the beneficial role of apologies in dispute resolution); Arthur Rosett \& Hiroshi Wagatsuma, The Implications of Apology: Law and Culture in Japan and the United States, 20 LAw \& Soc'Y REv. 461 (1986) (discussing the different roles that an apology plays in American and Japanese dispute resolution).

37. For what remains, for me, the most eloquent statement of how mediators have values, that include presiding over "fairness" and not genuflecting unnecessarily to "neutrality," see Lawrence Susskind, Environmental Mediation and the Accountability Problem, 6 VT. L. Rev. 1 (1981); see also Jennifer Gerarda Brown, Ethics in Environmental ADR: An Overview of Issues and Some Overarching Questions, 34 VAL. L. REv. 403 (2000) (considering the ethics of mediator activism in environmental ADR cases and discussing whether or not attorneys have an ethical obligation in such cases to ensure that the interests of outsiders are somehow accounted for and expressed).

38. Robert A. Baruch Bush, Mediation and ADR: Insights From the Jewish Tradition, 28 Fordham URB. L.J. 1007 (2001). 
(those they have a hand in making) rather than having to accept a verdict imposed from outside, even if from a wise elder. Compromise, it is said, provides for peace. Adjudication produces winners and losers who will continue to seek rectification (appeal) or wreak vengeance or revenge on each other and so litigation continues the fighting and battles. But I would suggest that our secular humanism has made progress beyond the Talmud. Compromise may produce the same sense of arbitrary peace and injustice, if, for example, we simply "split the difference" to achieve peace and closure. Instead, as I have argued in many articles, ${ }^{39}$ rather than compromise, where each party is likely to feel as if they have still "given up something," we should seek to meet each other's needs and interests and not cut the orange $\mathrm{e}^{40}$ or chocolate cake ${ }^{41}$ in half. Professor Bush would suggest that compromise includes the deeper religious value of "charity"- that we learn to give up more than we have to when we compromise and learn to "lose our self" in recognition of the other. ${ }^{42}$ I agree that generosity is a value we seek to foster in ADR, but I wonder whether "giving up" to the other side may encourage feelings of patronization, resentment, and "unjust enrichment." Achieving a "fair" result, rather than a compromise, appeals to me as a more appropriate expression of the values that inform good mediation (or negotiation). This is what I believe Rabbi Hillel meant when he said, "If I am not for myself, who will be for me?" and "If I am only for myself, what am I?"43 We can seek ways for righteousness, justice and recognition of both (or all) ${ }^{44}$ parties to a mediation. ${ }^{45}$ Compromise need not mean "meet-

39. E.g., Carrie Menkel-Meadow, Toward Another View of Legal Negotiation: The Structure of Problem Solving, 31 UCLA L. REV. 754 (1984).

40. Roger Fisher \& William URy, Getting to YES 73 (2d ed. 1991).

41. Menkel-Meadow, supra note 39, at 781.

42. Bush, supra note 38.

43. Pirke Aвoth: Sayings of the Fathers 1:14 (Isaac Unterman, ed. \& trans., 1964).

44. It is important to recognize that many legal and other problems that are brought to ADR are no longer about two parties only. Many modern legal problems involve multiple parties and multiple stakeholders. E.g., LAWRENCE SussKIND ET AL., The Consensus Building HandBooK (1999) (describing and illustrating the multiparty, multi-issue social and legal disputes common in our culture today, including environmental, municipal finance, health care, abortion, and resource allocation problems); Carrie Menkel-Meadow, The Trouble with the Adversary System in a Postmodern, Multicultural World, 38 WM \& MARY L. Rev. 5 (1996) (discussing the weaknesses of the modern binary adversarial system and possible approaches to address its deficiencies).

45. See Menkel-Meadow, supra note 25, for my argument that transformation, empowerment, and recognition, the "spiritual" values of ADR, are not inconsistent with each other and most often are paired with the instrumental "problem-solving" aspects 
ing halfway" or "giving something up." Solutions can be reached in which parties seek to meet each other's complementary needs without "giving in." 46

To the extent that mediation ideology contains within it the value of respect for the other, or reciprocity, then one should consider the Golden Rule as a useful and, perhaps, almost universal, expression of how parties (and their lawyers) ${ }^{47}$ might deal with each other in dispute resolution settings. Treating others as one would want to be treated suggests both substantive and process values informed by both "spiritual respect" and "secular justice" concerns. When reciprocity works most effectively, it encourages a stance of mutual respect and real, as well as "active, listening" to the other. It also facilitates the kind of re-ordered private norm creation that caused one "god" of mediation (Lon Fuller) to suggest that mediation's basic purpose is its ability to "reorient the parties to each other." 48

Thus, to conclude, mediation and various other forms of ADR practices are informed by some basic core values, accepted almost universally by different religious and spiritual disciplines. As a form of peacemaking, mediation with its emphasis on healing, human understanding, apology and acknowledgment of wrong, and anticipation of improved future relationships expresses human possibilities for transcendence in conflict resolution. Mediation also, however, as I have argued here, serves important secular humanist values and we should not forget these. If we are to empower, rec-

of ADR. One is unlikely truly to solve a problem without some recognition and shared worldview (at least for purposes of making an agreement), and empowerment and recognition cannot really occur if some outcome is not achieved that makes the parties feel whole, as well as holy.

46. The moral conception of compromise is actually quite complex, connoting sometimes weakness and arbitrariness in "giving up," but also sometimes facilitating continued relations. Our concerns are when "compromise" seems to connote giving up a moral principle, unless the larger moral principle is preserving the greater union or relationship. For a longer discussion of compromise, see generally COMPROMISE IN Ethics, Law and Politics (J. Roland Pennock \& John W. Chapman eds., 1979) and Mary Parker Follett, Constructive Conflict, in MARy Parker Follett: Prophet of Management: A Celebration of Writings From the 1920's 67 (Pauline Graham ed., 1996). For the role of compromise in political constitution making see, for example, Jack N. Rakove, Original Meanings: Politics and Ideas in the Making OF THE CONSTitution 57 (1996).

47. For my argument that lawyers ought to apply the Golden Rule when dealing with their own clients, see Carrie Menkel-Meadow, Lying to Clients for Economic Gain or Paternalistic Judgment: A Proposal for a Golden Rule of Candor, 138 U. PA. L. Rev. 761 (1990).

48. Lon Fuller, Mediation: Its Form and Its Functions, 44 So. CaL. L. Rev. 305, 308 (1971). 
ognize, and conciliate with others, we also must have justice, good faith, honesty, and some transparency about our processes and the outcomes they create. Although there are many aspects of mediational values that lend themselves to the "do be" list (positive things), we also must take account of the "don't be's" (remember the Ten Commandments are mostly exhortations of what not to do- "thou shalt nots"). ADR or mediation should not be used to pacify legitimate grievances or conflicts that need to be expressed. ADR should not produce "unjust" outcomes (whatever those might be, both for the parties affected by a particular dispute, as well as those inside of it) ${ }^{49}$ As we seek to focus on the future, we cannot forget the past. ${ }^{50}$

If mediation is to express fully the values we hope for it, we face some interesting, if daunting, tasks ahead. First, given the diversity of "sources" of values for religious, spiritual and secular humanist inspirations for ADR practices, should we simply acknowledge a multiplicity of sources and "let a thousand flowers bloom?" What if one person's sacred recognition is another's feeling of patronization? What ought the role of the mediator to be? Facilitator of compromises? Active participant in morally constructed narratives? Peaceseeker? Ceremonial healer? Should we eliminate mechanistic groundrules (e.g., turntaking, or no interruptions) to allow greater spiritual and more spontaneous feelings to be expressed? Discussion about values informing professional practices often devolve into discussions about prudence and judgment versus rules. I have spent the last five years drafting ethical standards and principles for the practice of ADR in both individual and provider group settings ${ }^{51}$ and I remain agnostic on the question of whether

49. Carrie Menkel-Meadow, Whose Dispute Is It Anyway? A Philosophical and Democratic Defense of Settlement (In Some Cases), 83 GEo. L.J. 2663, 2696 (1995).

50. For me, Trina Grillo eloquently expressed the concern that peace and future orientedness in mediation was disregarding the past in an unjust way. Trina Grillo, The Mediation Alternative: Process Dangers for Women, 100 YALE L.J. 1545 (1991); see also Carrie Menkel-Meadow, What Trina Taught Me: Reflections on Mediation, Inequality, Teaching and Life, 81 MiNN. L. REv. 1413 (1997) (reminding mediators to focus on the past, as well as the future, when reconciling parties to each other). Many others, like Sara Cobb, are now exploring the importance of fully elaborated narratives, including the reporting of past harms and pains, as necessary to a truly healing practice of mediation and reconciliation. For an interesting work exploring the benefits and drawbacks of various forms of compensatory and non-compensatory measures to redress the suffering of victims of mass atrocities, see MARTHA Minow, Between Vengeance and Forgiveness: Facing History After Genocide and Mass Violence (1998).

51. Carrie Menkel-Meadow, Ethics in ADR: The Many "Cs" of Professional Responsibility and Dispute Resolution, 28 FORDHAM URB. L.J. 979 (2001). 
good values, good people, market forces, or elaborate ethical rule systems ultimately will control our practice.

Second, it is one thing for us to focus on the "good values" that inform the best of conflict resolution or mediation practice. But as long as the practice of law continues to reward "hired guns," bottom-lines, or simply people who prefer a good fight or a good argument, ${ }^{52}$ the healing values of lawyering must be transmitted not only to the mediators, but to the lawyers who appear in mediation and their clients. This is one place that legal work and education is heading, but instead of our lawschools teaching the "healing arts," or problem solving, I see courses on "mediation advocacy," an oxymoron that promises to continue traditional adversarial combat values and import them into newer forms of conflict resolution.

\section{Conclusion}

It seems important to me that the sacred, religious, and spiritual values that inform most of what is good about conflict resolution should not be cabined to the church, synagogue, mosque, or zendo. To achieve peace, justice, reconciliation, intersubjective understanding, solutions of good quality to conflicts, as well as productive uses of conflict, we must consider the secular humanist values of self-determination and autonomy, as well as interdependence and mutual caring, both when they coincide with religious values, and also when they differ. As a member of the Ethical Culture Society, and as a member of the human race, I still believe that "god" is spelled with two "o's." What that means in lawyering and conflict resolution practice remains to be elaborated. The challenge will be to see whether we can join pursuit of connection, communion, and collective meaning with autonomy, self-determination, and justice. Good conflict resolution practice recognizes that when ADR works, our knowledge and understanding transcend different conceptions of facts, interpretations, and meaningmaking systems. We find value in the valuing of our fellow human beings.

52. Despite all the claims that lawyers are dissatisfied with their work, see Joseph Allegretti, A Christian Perspective on Alternative Dispute Resolution, 28 Fordham URB. L.J. 997 (2001), many lawyers I know still claim to love their work because they "love to win," "love to make a good argument," "love to cut a good deal," "fight for justice," etc. Perhaps someone ought to explore the secular, not-so-humanist, values that still motivate many conventional lawyers. And this, of course, does not include the younger generation, many members of which do not even want to practice law if there are other ways of making a more comfortable and bigger living. 


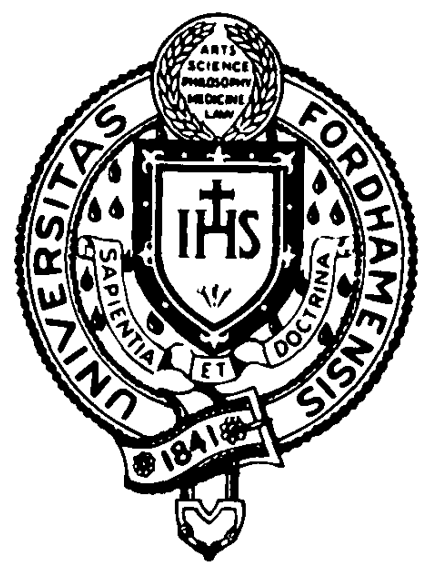

HeinOnline -- 28 Fordham Urb. L.J. 1088 2000-2001 